\title{
Immunological Specificity of Helicobacter pylori Urease and Identification by Immunological Detection of Its Specific Urease
}

\author{
Masao SHINGAKI, Akemi KAI, Takeshi ITOH and Ichiro HIRATA* \\ The Tokyo Metropolitan Research Laboratory of Public Health \\ *Tama Branch Laboratory, The Tokyo Metropolitan Research Laboratory of Public Health \\ (Received: June 10, 1993) \\ (Accepted: August 6, 1993) \\ Key words: Helicobacter pylori, Helicobacter mustelae, urease, latex agglutina- \\ tion
}

\begin{abstract}
Helicobacter pylori urease was recovered as a single peak by DEAE-Sepharose column chromatography and Sephacryl S-200 gel filtration. The purified urease was obtained by fast protein liquid chromatography using a Mono Q column. The purified urease preparation gave a single band in polyacrylamide gel disc electrophoresis.

Latex particles were sensitized with anti-urease immunoglobulin. The sensitized latex particles were agglutinated with the purified urease and by cell sonicates obtained from 55 strains of $H$. pylori which were isolated from the gastric mucosa of patients with gastric and duodenal disorders, while they did not react with those obtained from related bacteria known to be urease producers, such as Helicobacter mustelae and urease- positive "Campylobacter lari variants", or by urease of some strains of Enterobacteriae. We have developed a specific and sensitive method for detecting the urease by using the reversed passive latex agglutination technique, in order to identify of the organism.
\end{abstract}

\section{Introduction}

Recently a possible role of Helicobacter pylori in the etiology of chronic gastritis and gastric or duodenal ulcers has been proposed by several workers ${ }^{1 \sim 3}$. The organism has been detected at a high frequency in biopsy specimens of gastric mucosa from patients with gastric diseases. This organism produces urease, and in this way differs from species of Campylobacter. The fact that $H$. pylori produces urease was first observed in a strain isolated by Langenberg et $\mathrm{al}^{44)}$ in the Netherlands in 1984 . Owen et $\mathrm{al}^{5)}$ confirmed this characteristic property of $H$. pylori in strains isolated in Australia, West Germany and the United Kingdom. The urease of $H$. pylori has been described as a highly active enzyme, more active than that of urease produced by Proteus species. Indeed, H. pylori urease has been directly detected in biopsy specimens from patients with gastritis. We developed a specific and sensitive method for detecting the enzyme by using the reversed passive latex agglutination (RPLA) technique and used it to identify the organisms.

\section{Materials and Methods}

Bacterial strains: H. pylori strains NCTC 11637, NCTC 11638 and NCTC 11639, obtained from B.J. Marshall were clinically isolated, and 55 isolates of $H$. pylori were cultured from gastric biopsies of patients with gastritis, gastric ulcer and duodenal ulcer as previously described ${ }^{3)}$. As related bacteria 4 strains of $H$.

別刷請求先：(广T169) 東京都新宿区百人町 3-24-1

東京都立衛生研究所新垣 正夫 
mustelae (NCTC 12032, F6, F7, F10) were received from D.S. Tompkins and R.J. Owen and 8 were isolated from ferret stomach. Two strains of urease-positive "Campylobacter lari variants" were provided by FJ. Bolton. As urease-positive Enterobacteriaceae, 4 strains of Proteus mirabilis, one strain of Proteus vulgaris, 4 strains of Providencia rettgeri and two strains of Yersinia enterocolitica isolated from human feces were used.

Bacterial growth for purification of urease and cell-free extract: $H$. pylori NCTC 11638 was cultured at $37^{\circ} \mathrm{C}$ for 2 days in blood agar medium under microaerophilic conditions, and the cells (3.45 g) were harvested and suspended in PEM buffer (20 mM phosphate buffer, $1 \mathrm{mM}$ EDTA, $1 \mathrm{mM}$ 2-mercaptoethanol, $\mathrm{pH}$ 7.0). The cell suspension was centrifuged, washed with PEM buffer and disrupted with a French press Model No. $5501 \mathrm{M}$ type, Ohtake Seisaku Inc., Tokyo, Japan) under $1,000 \mathrm{~kg} / \mathrm{cm}^{2}$ pressure. The suspension of disrupted cells was centrifuged $(14,000 \mathrm{rpm}, 20 \mathrm{~min})$ to remove the cellular debris, and the supernatant was filtered through a $0.45-\mu \mathrm{m}$ Millipore filter disk. this cell-free extract was used as crude starting material.

Cultivation of the strains used for immunological investigation of urease and cell-free extracts: $H$. pylori, $H$. mustelae and the "C. lari variants" were grown on blood agar medium at $37^{\circ} \mathrm{C}$ for 2 days under microaerophilic conditions. The cells were suspended in $10 \mathrm{ml}$ of PEM buffer and disrupted with an ultrasonic disrupted (model UR 200P, Tomy Seiko., Ltd., Tokyo) with 40 watts for 5 min and the filtrate was used for urease assay and for RPLA.

$P$. mirabilis, $P$. vulgaris, $P$. rettgeri and $Y$. enterocolitica were inoculated in to $10 \mathrm{ml}$ of brain heart infusion broth (Difco) containing $2 \%$ fillter-sterilized urea and cultured at $37^{\circ} \mathrm{C}$ for $4-5$ hours with shaking. The cells were subjected to ultrasonic treatment as described above.

Column chromatography: Urease was purified by chromatography on a DEAE-Sepharose CL-6B column $(2.5 \times 17 \mathrm{~cm})$, a Phenyl-Sepharose CL-4B column $(1.5 \times 32 \mathrm{~cm})$, and a Sephacryl S-200 SF column $(1.5 \times 88 \mathrm{~cm})$ at $4^{\circ} \mathrm{C}$ described by Haushinger $\left.{ }^{6}\right)$. Fast protein liquid chromatography on a Mono-Q column $(0.5 \times 5 \mathrm{~cm})$ and a Superose 6 column $(1.0 \times 30 \mathrm{~cm})$ was performed at room temperature (Fig. 1).

Gel diffusion test: The double gel diffusion test was performed by the method of Ouchterlony ${ }^{7)}$.

Polyacrylamide gel disc electrophoresis: Purity of the purified urease was determined by disc electrophoresis on a 7.5\% polyacrylamide gel with $0.1 \mathrm{M}$ tris-glycine buffer ( $\mathrm{pH} 8.3$ ) as described by Davis ${ }^{8}$.

Assays for urease: According to Chaney and Marbach $^{9)}$, urease activity indicates the amount of ammonia released from urea. Twenty $\mu$ l of urease was added to $1 \mathrm{ml}$ of PEM buffer (pH 7.0) containing 50 $\mathrm{mmol}$ of urea, and the mixture was incubated at $37^{\circ} \mathrm{C}$ for $10 \mathrm{~min}$. The released ammonia was measured by the Berthelot reaction. One unit of urease activity was defined as the amount that hydrolyzes $1 \mathrm{ml}$ of urea per min.

Rabbit antiserum to urease: Antiserum was produced in rabbits with purified urease plus Freund's complete adjuvant.

Purification of immunoglobulin from anti-urease serum: For this purpose a Protein A Sepharose CL-4B column $(1 \times 8 \mathrm{~cm})$ equlibrated with $0.1 \mathrm{M}$ tris- $\mathrm{HCl}$ buffer $(\mathrm{pH} 7.2)$ was used. Anti-urease serum was added to the column. After being washed with $0.1 \mathrm{M}$ tris-HCl buffer $(\mathrm{pH} 7.2)$ to remove the non-adsorbed material, antiserum was eluted with a $3 \mathrm{M} \mathrm{NH}_{4} \mathrm{CN}$ solution to separate IgG. The IgG fraction was concentrated with a PM-10 ultrafilter (Amicon) and applied to a Sephadex G-25 column $(2.6 \times 40 \mathrm{~cm})$ equilibrated with $1 / 15 \mathrm{M}$ PBS (pH 7.2) to remove $\mathrm{NH}_{4} \mathrm{CNS}$.

Anti-urease immunoglobulin-sensitized latex: Polystyren latex particles (SDL-59, $0.9 \mathrm{~m}$ in diameter, Takeda Chemical Industries, Ltd., Osaka) were suspended in 1/15 M PBS (pH 7.2) to $0.25 \%$ concentration. This suspension was mixed with an equal volume of a $15-20 \mu \mathrm{g} / \mathrm{ml}$ solution of anti-urease immunoglobulin prepared as above and sensitized at room temperature for 1 hour (Fig. 2). The sensitized latex particles 
Fig. 1 Procedure for purifying urease of $H$. pylori

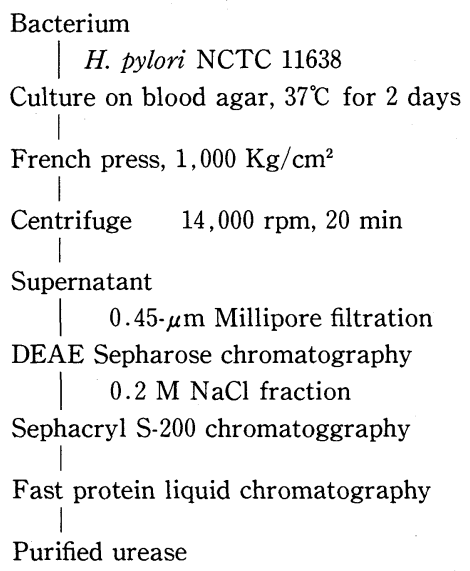

Fig. 2 Procedure for coupling anti-urease IgG to polystyrene latex particles

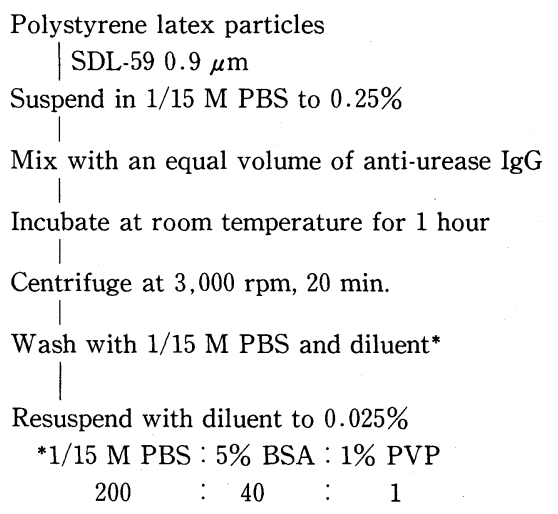

were adjusted to $0.025 \%$ concentration with the diluent.

Reversed passive latex agglutination: Various cell extracts were examined for urease by microplate agglutination. Forty-fold serial dilution of purified urease and the cell extracts were prepared and $0.025 \mathrm{ml}$ of each dilution was inoculated on a flat type microtiter plate, and $0.025 \mathrm{ml}$ of a $0.025 \%$ suspension of sensitized latex particles was added to each plate. The plates were allowed to react in a humidified box at room temperature for $12-16$ hours. Latex particles sensitized with normal rabbit immunoglobulin were used as a control.

\section{Results}

1. Purification of urease

Cultivated of $H$. pylori NCTC 11638 cells were disrupted with the French press, and the supernatant after centrifugation was chromatographed on DEAE-sepharose equilibrated with PEM buffer. After the urease was eluted with PEM buffer. After the urease was eluted with PEM buffer containing $0.2 \mathrm{M} \mathrm{NaCl}$, further elution was performed with PEM buffer containing $0.5 \mathrm{M} \mathrm{NaCl}$. Urease activity was detected as a single peak in the PEM buffer fraction containing $0.2 \mathrm{M} \mathrm{NaCl}$. The active fractions were chromatographed on a Phenyl-Sepharose CL-4B column equilibrated with PEM buffer containing $2 \mathrm{M} \mathrm{NaCl}$, and urease was eluted with PEM buffer. The concentrated fractions were subjected to gel filtration on a Sephacryl S-200 Superfine column equilibrated with PEM buffer. To remove remaining impurities. The filtrate was subjected to fast protein liquid chromatography on a Mono- $Q$ colium. The urease showing a single peak was eluted with a linear gradient from 0 to $2 \mathrm{M} \mathrm{NaCl}$ in PEM buffer (Fig. 3). Final chromatography was on a Superose 6 column for desalting. Urease was purified 80.7 -fild by the above process, and the overall recovery was $9.5 \%$. The purified urease showed a single band on polyacrylamide gel disc electrophoresis.

2. Immunological specificity of purified urease

Antisera were prepared by immunizing rabbits with crude urease obtained by DEAE-Sepharose chromatography and with purified urease, and tested for immunological specificity by the Ouchterlony gel diffusion method. Crude urease gave three precipitin lines with crude antiserum, but purified urease gave a single precipitin line with anti-purified urease serum and anti-crude urease serum (Fig. 4).

3. Detection of $H$. pylori urease by RPLA

The latex particles sensitized with anti-urease immunoglobulin showed agglutination by purified urease on the microtiter plate. Using the purfied urease, RPLA was used to determine the minimum 
Fig. 3 Fast protein liquid chromatography of $H$. pylori urease on a Mono- $\mathrm{Q}$ column. The absorbance was monitored at $280 \mathrm{~nm}(-)$, and urease activity (-.-) was determined for aliquots of $0.5 \mathrm{ml}$ fractions. $(\cdots)$ linear gradient of $\mathrm{NaCl}$.

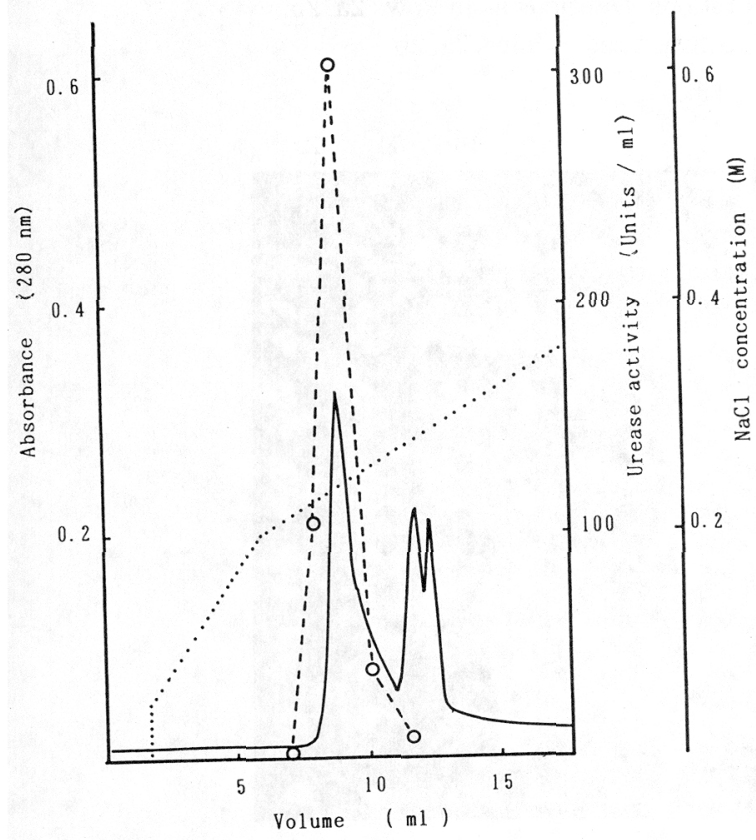

Table 1 Reactivity of urease from cell extracts of $H$. pylori and other bacteria with latex particles coupled with anti-urease immunoglobulin

\begin{tabular}{|c|c|c|}
\hline Organisms & $\begin{array}{l}\text { RPLA titer by } \\
\text { Anti- } H \text {. pylori } \\
\text { urease }\end{array}$ & $\begin{array}{c}\text { Urease } \\
\text { activity } \\
\text { (units/ml) }\end{array}$ \\
\hline \multicolumn{3}{|l|}{ H. pylori } \\
\hline NCTC 11637 & $10,240^{\mathrm{b}}$ & 112.3 \\
\hline NCTC 11638 & 40,960 & 115.4 \\
\hline NCTC 11638 & 10,240 & 103.2 \\
\hline Isolates $(n=55)$ & $10,240-40,960$ & $37.1-132.1$ \\
\hline \multicolumn{3}{|l|}{ H. mustelae } \\
\hline NCTC 12032 & - & 125.5 \\
\hline F 6 & - & 182.6 \\
\hline F 7 & - & 48.0 \\
\hline F 10 & - & 29.1 \\
\hline Isolates $(n=7)$ & - & $31.1-152.4$ \\
\hline \multicolumn{3}{|l|}{ "C. lari vari." } \\
\hline $10231 / 7 / 83$ & - & 23.0 \\
\hline $3980 / 1 / 83$ & - & 23.5 \\
\hline Proteus spp $(n=5)$ & - & $31.6-35.5$ \\
\hline Providencia sp $(\mathrm{n}=4)$ & - & $19.3-28.4$ \\
\hline Yersinia $\mathrm{sp}(\mathrm{n}=2)$ & - & $7.1-30.3$ \\
\hline Jack bean & - & 355.4 \\
\hline
\end{tabular}

a ) Units of urea hydrolysed $/ \mathrm{min} / \mathrm{ml}$

b) The reciprocal of the highest dilution exhibiting agglutination by RPLA

Fig. 4 Ouchterlony double gel diffusion test of purified urease of $H$. pylori (A) with anti-purified urease serum (B) and anti-crude urease serum (C).

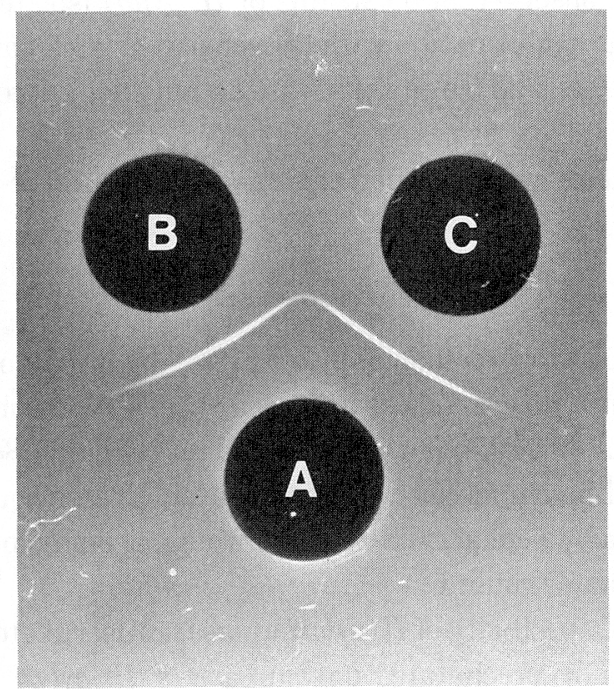


Fig. 5 Detection of $H$. pylori urease by RPLA

Rows la to 4a: Anti-urease IgG-sensitized latex particles.

Rows $1 \mathrm{~b}$ to 4b: Normal IgG-sensitized latex particle.

Rows 1a, 1b: Purified urease. Well 1, $13.0 \mu \mathrm{g} / \mathrm{ml}$. Wells 2-12, 4-fold serial dilutions.

Rows 2a, 2b: Cell extract from $H$. pylori NCTC 11638.

Well 1, undiluted. Wells 2-12, 4-fold serial dilutions. Dilutions as in Rows 2a, 2b.

Rows 4a, 4b: Cell extract from P. mirabilis.. Dilutions as in Rows 2a, 2b.

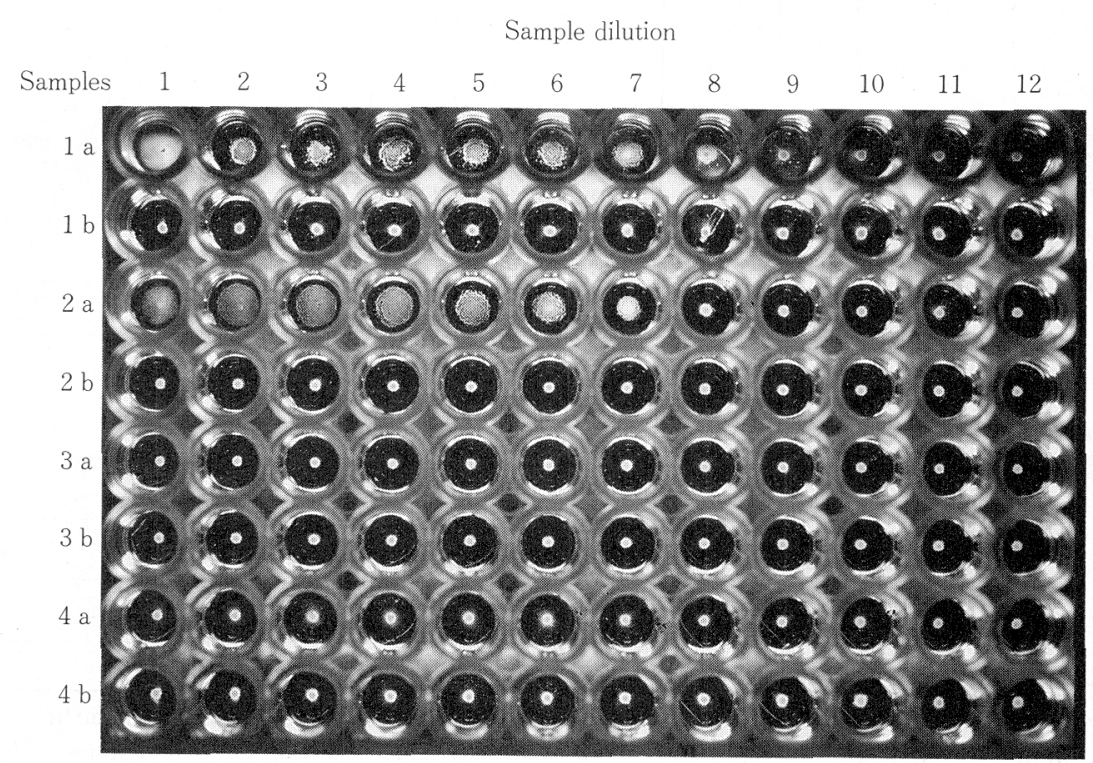

detectable amount of urease in the microtiter plate. Serial 4-fold dilutions of a concentration of $13.0 \mu \mathrm{g}$ of purified urease per $\mathrm{ml}$ were agglutinated up to by the sensitized latex particles (Fig. 5). It was deduced from these results that the RPLA method can detect urease in a concentration of $1 \mathrm{ng}$ per ml.

Immunological specificity of urease produced by $H$. pylori and that of ureases of other bacteria was investigated by RPLA. The sensitized latex particles showed high agglutination titer from 1:10,240 to 1:40,960, with H. pylori NCTC 11637, NCTC 11638 and NCTC 11639 (Table 1). Further, agglutination titer from 1:10,240 to 1:40,960 were observed in 55 strains of $H$. pylori isolated from gastric mucous. Eleven strains of $H$. mustelae showed no agglutination with the sensitized latex particles. Furthermore, two strain of "C. lari variants" showed 23.0 and 23.5 units of urease activity per ml, respectively, but they also did not react with these ureases.

The sensitized latex particles were neither agglutinated by urease-positive Enterobacteriaceae nor reacted with Jack bean urease.

\section{Discussion}

In order to develop a method for detecting $H$. pylori urease by immunological means, the authors first purified the urease of this strain. The urease was absorbed on a DEAE-Sepharose CL-6B column and eluted with PEM buffer containing $0.2 \mathrm{M} \mathrm{NaCl}$. It was absorbed on a Phenyl-Sepharose CL-4B column with a buffer of $2.0 \mathrm{M} \mathrm{NaCl}$ and could be eluted with salt-free buffer. Urease could not be completely separated from any contaminating protein by Sephacryl S-200 SF chromatography, but it was purfied by fast protein liquid chromatography on a Mono-Q column.

To study the immunological specificity of $H$. pylori urease, antiserum to the urease was prepared, since the present antiserum specifically precipitated only urease of $H$. pylori. Guo and Liv ${ }^{10)}$ and Jones and 
Mobley ${ }^{11)}$ reported that urease of $P$. vulgaris is immunologically related to that of $P$. mirabilis but differs from that of Morganella morganii. These observation suggested that ureases produced by bacteria have immunological specificity for the genus of species. Therefore, the detection of urease based on RPLA was investigated by binding anti- $H$. pylori urease immunoglobulin to polystyrene latex particles. Anti- $H$. pylori urease serum reacted with urease of $H$. pylori but showed no reaction with urease-positive $H$. mustelae isolated from ferret gastric mucous or "C. lari variants" which can produce urease or with ureases produced by $P$. mirabilis, $P$. vulgaris, $P$. rettgeri and $Y$. enterocolitica. These results show that the urease of $H$. pylori has significant immunological specificity.

Since $H$. pylori urease may play a role in gastritis and has been shown to be an important colonizer in gastric mucosa ${ }^{12,13,14)}$, the enzyme urease is the most studied of all the $H$. pylori products. It was found to be an extremely active protein with a molecular mass of about $600 \mathrm{kDa}$, and isoelectric point of 5.9 and composed of two subunits ${ }^{15,16)}$. The native urease enzymes of $H$. mustelae, $H$. felis and $H$. nemestrinae were recently found to be almost identical in molecular mass and isoelectric point ${ }^{17}$. It is necessary to define the relationschip of immunological properties to the physical characteristics of the ureases in Helicobacter species.

\section{Acknowledgments}

We thank the following individuals for providing strains used in this study: B.J. Marshall, the University of Virginia School of Medicine, USA, F.J. Bolton, Public Health Laboratory, Preston, UK, D.S. Tompkins, University of Leeds, UK, and R.J. Owen, Central Public Health Laboratory, UK.

\section{Referecnes}

1) Goodwin, C.S., Armstrong, J.A. \& Marshall, B.J.: Campylobacter pyloridis, gastritis, and peptic ulceration. J. Clin. Pathol. 39: 353-365, 1986.

2) Blaser, M.J.: Helicobacter pylori and the pathogenesis of gastroduodenal inflammation. J. Infect. Dis., 161: 626-633, 1990.

3) Itoh, T., Yanagawa, Y., Shingaki, M., Takahashi, M., Kai, A., Ohashi, M. \& Hamana, G.: Isolation of Campylobacter pyloridis from human gastric mucosa and characterization of the isolates. Microbiol. Immunol. 31: 603-614, 1987.

4) Langenberg, M.L., Tytgar, G.N.L., Schipper, M.E.I., Rietra, P.J.G.M. \& Zanen, H.C.: Campylobacter-like organisms in the stomach of patients and healthy individuals. Lancet. i: 1284, 1984.

5) Owen, R.J., Martin, S.R. \& Borman, P.: Rapid urea hydrolysis by gastric Campylobacter. Lancet. i: 111, 1985.

6) Hausinger, R.P.: Purification of a nickel-containing urease from the rumen anaerobe Selenomonas ruminantium.J. Biol. Chem. 261: 7866-8770, 1986.

7) Ouchterlony, O.: Antigen-antibody reactions in gels. Acta Pathol. Microbiol. Scand. 26: 507-515, 1949.

8) Davis, B.J.: Disc electrophoresis II. Method and application to human serum proteins. Ann. N.Y. Acad. Sci. 121: 404-427, 1964.

9) Chaney, A.L. \& Marbach, E.P.: Modified reagents for determination of urea and ammonia. Clin. Chem. 8: 130-132, 1962.

10) Guo, M.M.S. \& Liu, P.V.: Serological specificites of ureases of Proteus species. J. Gen. Microbiol. 38: 417-422, 1965.

11) Jones, B. \& Mobley, H.L.T.: Genetic and biochemical diversity of ureases of Proteus, Providencia, and Morganella species isolated from urinary tract infection. Infect. Immun. 55: 2198-2203, 1987.

12) Hazell, S.L., Borody, T.J., Gal, A. \& Lee, A.: Campylobacter pyloridis gastritis I: Detection of urease as a marker of bacterial colonization and gastritis. Am. J. Gastroenterol. 82: 292-296, 1987.

13) Eaton, K.A., Brooks, C.L., Morgan, D.R. \& Krakowka, S.: Essential role of urease in pathogenesis of gastritic induced by Helicobacter pylori in gnotobiotic piglets. Infect. Immun., 59: 2470-2475, 1991.

14) Ferero, R.L. \& Lee, A.: The importance of urease in acid protection for the gastric-colonising bacteria Helicobacter pylori and Helicobacter felis sp. nov. Microb. Ecol. Health Dis. 4: 121-134, 1991.

15) Evans, DJ., Evans, D.G., Kirkpatrick, S. \& Graham, D.Y.: Characterization of the Helicobacter pylori urease and purification of its subunits. Microb. Pathog., 10: 15-26, 1991.

16) Tompkins, D.S., Millar, M.R. \& West, A.P.: Isoelectric focusing of ureases from Campylobacter pylori and related 
organisms. J. Clin. Microbiol., 26: 2678-2679, 1988.

17) Turbett, G.R., Hoj, P.B., Horne, R. \& Mee, B.J.: Purification and characterization of the urease enzymes of Helicobacter species from humans and animals. Infect. Immun., 60: 5259-5266, 1992.

\section{Helicobacter pylori が産生するウレアーゼの免疫学的特異性と ラテックス凝集反応による本菌の同定 東京都立衛生研究所, ${ }^{*}$ 東京都立衛生研究所多摩支所
新垣 正夫 甲斐 明美 $\quad$ 伊藤 武 平田 一郎* \\ (平成 5 年 6 月 10 日受付) \\ (平成 5 年 8 月 6 日受理)}

要旨

Helicobacter pylori のウレアーゼを免疫学的な 手段により検出する方法を開発するため，本菌の ウレアーゼの精製を行った。 H. pylori NCTC11638株の菌体をフレンチプレスで破壊 し, 菌体成分を除去した上清液から, 各種のク口 マトグラフィーにより精製したウレアーゼは polyacrylamide gel disc electrophoresisにより 単一なバンドが得られた。さらに精製したウレ アーゼを家鬼に免疫して作成した抗ウレアーゼ血 清は H. pylori のウレアーゼと反応し，Yersinia enterocolitica のウレアーゼとは反応しなかった。 本抗血清からアフィニティークロマトグラフィー
により IgG 画分を精製し，ラテックス粒子に感作 させた。本感作ラテックスは H. pylori の精製ウ レアーゼ执よび H. pylori 55菌株のウレアーゼと 明瞭に凝集反応したが， H. mustelae のウレアー ゼとは反応しなかったし，ウレアーゼを産生する “Campylobacter lari variants”とも反応しなかっ た.さらに本感作ラテックスは Proteus mirabilis, $P$. vulgaris, $P$. rettgeri, $Y$. enterocolitica のそれ ぞれのウレアーゼとも反応しなかった。著者らは H. pylori の産生するウレアーゼの免疫学的な特 異性を指摘するとともに, ラテックス凝集反応に より H. pyloriを簡易に同定できることを明らか にした。 